\title{
The Figurative Basis of Russian Dialectal Words and Expressions with the Meaning of Negative Assessment of Social Changes*
}

\author{
TATYANA LEONTYEVA \\ Russian State Vocational Pedagogical University, Mashinostroiteley, 11, RU-620098 Yekaterinburg \\ E-mail: leotany@mail.ru
}

(Received: 4 September 2017; accepted: 30 November 2017)

\begin{abstract}
The paper presents the results of a study of metaphorical vocabulary with the meaning of assessment of social change. The analysis involves common Russian vocabulary as well as the material of Russian dialects. Previously unpublished expeditionary records of dialect speech are introduced into academic discussion. Special attention is paid to the onomasiological analysis of linguistic facts. Four groups of motives are revealed: the motives of destruction (loosening, turning inside out, and death); spatially dynamic motives (moving away and disappearance); the motives of qualitative changes (the loss of one's own properties and status, the acquisition of similarity with representatives of a foreign nation, the acquisition of worse properties, cooling down); and the motives of confusion (mixing of different cultures and disorientation). It is shown that the bearers of traditional folk culture tend to evaluate the changes of any kind as undesirable. A disapproving assessment of social change is due to the orientation of traditional culture toward strict adherence to customs.
\end{abstract}

Keywords: Russian dialects, semantics, ethnolinguistics, social change, traditional society

\section{Introductory notes}

Words and phrases that characterize the destruction of social principles, rules, and norms are very frequent in Russian dialectal discourse. It is understandable since Russian dialects correlate with traditional folk (peasant) culture, and "traditional consciousness has a higher degree of 'socialization' than the consciousness of the modern bearer of bookish culture" (БЕРЕзОВИч 2007: 27). In other words, rural culture based on traditional consciousness and custom is focused on preserving old norms as a bulwark of stability, while accumulating changes are perceived negatively, that is, they are assessed as undermining the social foundation.

What exactly are the changes in society which receive a disapproving response from the speakers of Russian dialects? The focus is, first of all, on changes in the way of everyday life and morals of a whole generation, and, secondly, on a single person's reprehensible behaviour which contradicts the ethical standards of human behaviour established in the given society. Sometimes, the respondent gives a very general assessment implying overall and large-scale changes. In other instances,

* This study is supported by the Russian Science Foundation (project No. 16-18-02075 "Russian Society in the Mirror of Lexical Semantics"). 
on the contrary, the informant comments on the particular manifestation of social transformations in the sphere of human actions. In the first type of occurance, the statement of global changes in the society obscures the matter in the sense of the correctness of the cognitive interpretation of the material under study (the fact of the changes is merely stated but no argumentation is given, for example: Tяnёрешний народ хужны расы утренней - СПП 2001: 113), whereas in the second model, the respondents' appeal to individual cases of social violations sheds light on "sensitive areas" which are subject to evaluation - non-observance of religious orders, disrespectful attitude toward elders, new behavioural features of the youth, еtс.: Здесь все заблудились, ни постов, ни церкви (СРГК 2: 82); Такое нынче разбитие пошло: брат на брата, сын на отца, молодежь табак курит, картами играет (СРНГ 33: 263); Мы дак опоганились: когды переверну стакан, а когды уж не переверну (СРГК 4: 217). It is remarkable that often the so-called "internal form of the word" is in each occurance transparent and usually contains traces of the interpretation of the phenomenon which became the object of nomination as undesirable, that is, it passes its negative evaluation through employing motives of destruction (разбитие) by the nominator, the lack of reference points (заблудились), and pejorativity (опоганились, хуже утренней росы).

However, as it turned out, the changes condemned by the informant are not necessarily "bad". For example, there is nothing reprehensible in the organization of life on the basis of the analysis of the illustrative context to the apx. pýmuться 'to break down, change (about customs, way of life, and traditions)': Да в домах всё рушится, по-новому в домах-то, по нонешней-то моде (СРГК 5: 587). This leads us to a remarkable conclusion: the destructive role of the fact of change is established not so much on the basis of its pejorative quality, but on the basis of the conviction that any change is detrimental (and therefore undesirable). In the view of the bearers of folk culture, any change displays the signs of decline, the destruction of social norms, i.e. the evidence of social degradation (in dictionaries of modern Russian, degradation is defined as 'gradual deterioration, the loss of valuable properties and qualities, decline'). Therefore, when referring to the object of nomination as applied to the lexical material under study, we cannot speak about negative changes, it will be more appropriate for the semantic construct embodied in the analyzed nominations to be called negative evaluation of any change.

The mental construct "attitude to change" expressed in the lexicon connected with the categories "past" and "present" lies in the temporal image of the world. Therefore, it falls into the zone of attention of researchers studying the lexical representations of the category "Time".

It is extremely frequent in dialectic discourse to talk about the past and the future in a comparative context. In one of her publications, S. Belyakova analyzes "the ideas about the past and the future that exist in the linguistic consciousness of modern dialect speakers reflected on the lexical-phraseological level" (БЕляковА 2005: 79). Commenting on the functioning of verbal markers of time (раньие, прежде, прошльй, допрежной, ранешной, etc.) in the dialect texts recorded in the Tyumen region (Преже не така жизнь была; Раньще семь деверей и семь 
снох вместе жили; Ране мужики были больии, а теперь бабы над мужиками больши), she makes an important observation: "In speech, these lexemes are most often used with a special communicative task: as a rule, they refer to another way of life which is compared (explicitly or implicitly) with the present" (БЕляковА 2005: 80). It is not surprising that in speech, time markers introduce fragments of reflection about the changes in society caused by the movement of time. Obviously, the speaker makes a connection between the given period and the state of society. It is not accidental that the nominations of temporal categories of nрошлое 'past', билое 'days of yore', and минувшее 'foregone' are defined in the dictionary of synonyms as "preceding the present period of time with the events and objects characteristic for it, or the events that occurred during a specified period" (HOCC 2003: 896). Compare also: "In paньше 'before', the idea of comparison is very important" (HOCC 2003: 941); and if paнbue 'before' is an adverb, "it is rather not the time that is compared but the situations themselves" (HOCC 2003: 941).

Yu. Gritskevich and V. Novikov consider the adverbial opposition paнbue (mогдa) 'earlier (then)' vs. meneps 'now' as one of the typical lexical indicators of the concept "Fashion" (ГРицКЕвич-Новиков 2011). Such comparisons can involve the individual circumstances of a person's life as well as social changes. Undoubtedly, similar contexts also exist in the speech of standard-language speakers, cf. a remark concerning the use of the adverb прежде 'before' in the standard language: "The word прежде is very often used in the context of nostalgic memories of times gone by" (HOCC 2003: 942). However, in dialect speech such statements are especially frequent: "The comparison of the past and the present is the hallmark of all the stories of dialect speakers about the way of rural life" (ПЕлиПЕнко 2009: 21). Such contexts which can be called "typical" are indicative of popular speech.

Over one hundred language units have been extracted from dialect dictionaries and card files using the method of continuous selection of vocabulary and phraseology. Words of various parts of speech have been involved in the research with the meaning 'about the loss of customs', 'about decay, ruining', 'to get worse (about life, people)', 'not to observe or respect, to forget the custom', 'non-observance of customs', 'the one who does not observe the customs, breaks the rules', 'not to live as one is supposed to', 'to abandon the customs, replacing them with new ones', 'to violate the norms of behaviour', 'to start behaving reprehensibly', 'to change for the worse', etc. In such cases, both the subject and the object of the evaluation are people representing the same social community, the subject-matter of the evaluation is human behaviour in relation to other people, customs, and things, while the basis of the evaluation is the understanding of the proper or normal for a given society. Along with eventual meanings ('human action' and 'change of state of society'), an interpreting component ('the qualification of the actions of the nomination object from the position of the speaker') is included into the semantic scope of such words. The experience of analyzing the values of the collected linguistic facts (with reference to contexts) was undertaken by the author earlier (ЛЕОНтьЕВA 2012). Next, the focus will be made on the onomasiological analysis of the words and expressions of one group, namely, the language units that characterize changes 
encompassing the whole society or a part of it, and the representations of changes in the behaviour of an individual will not be dealt with.

A motivational analysis of the collected vocabulary is used to describe ways of comprehension (peculiar to Russian linguistic consciousness) of the phenomena of reality that are regarded as evidence of undesirable changes in society. For this purpose, the author has analyzed linguistic facts having implications in the sphere of "Changes in society and in the behaviour of a generation" if their internal form captures the assessment of these changes. Next, a number of motives will be presented that underlie such common Russian and dialect language units.

\section{Motives of destruction in denotations of social changes}

Images put by the native speaker in the basis of evaluative indications of social transformations embody primarily the motives of loosening, turning inside out, and dying, and are united by the idea of the world's destruction. Man and society act as subjects of a non-objective action, that is, they are self-destructive.

\subsection{Motive 1: The loss of coupling between the parts of the whole, loosening}

Immorality, antisocial behaviour of a person are conceptualized as the emergence of oscillatory movements of an object, and the loss of a strong coupling between the parts of the whole.

For example, перм. раскольба́ться 'to lose moral foundations': Молодежьто нынче совсем раскольбалась (СПГ 2: 271) is secondary to the designation of swinging, cf. печор., свердл. раскольгба́ться 'to shake, swing': Как шатер весь у Митрея раскольбается; На качелях она раскольбалась, да чуть не пала (СРНГ 34: 128).

The перм. расхляббаться 'not to comply with the rules and norms of life adopted in the society': Раньше тожё муж жену учил всяко, а она молчала. Счас все грамотны стали, чуть чего - она уходит; расхлябались все. Счас сплошь и рядом расходятся (СПГ 2: 279) is semantically derived from the denotation of loosening, cf. the диал. расхля́бывать (расхля́бать) 'to loosen, make shaky, weaken, unrivet', диал. расхлябаться (also порасхля́баться) 'to shake apart, grind, get weakened from hitting, shaking, swinging': Гайки, винты в повозке расхлябались; Спицы в колесе все порасхлябались (ДАль 4: 82). These lexemes are probably related to the verb *xlębati, which has onomatopoeic nature (ЭССЯ 8: 32). Among its other continuants there are Russian verbs with the meaning of reeling, oscillatory movements that arise due to the loose fit of one object to another: pус. диал. хля́бать 'to swing, stagger, knock, strumble from a loose fit of things' (ДАль 4: 1200), хля́бать 'to stagger, loosen up, dry up' (Куликовский 1898: 128), ряз. хля́бать 'not to stay in one's place, not to stick to something' (ОссовецКИй 1969: 584). Cf. also волог. хля́бандать 'to be far too wide or too large in size (about clothes, shoes, harnesses, etc.)': Чтоб не хлябандала упряжь, чересседелом вяжут; Дак они ему хлябандают туфли-то (СРГК 6: 723). Тhе 
secondary meaning of general aggravation including intellectual, moral, and social degradation develops on the basis of the object meanings of these words: диал. здоровье расхлябалось, старик совсем расхлябался 'his health is flimsy' (Даль 4: 82), онеж. мозги хлябали 'the disorder of the nervous system' (СРГК 6: 723).

The semantic model "to loosen up, cease to be firm, strong, stable $\rightarrow$ to cease to behave in accordance with the accepted norms in society" is realized in words used to describe a large social group or a part of it, as evidenced by the collective subjects все and молодежь in contexts as молодежь раскольбалась, расхлябались все. This motive coincides with the image embodied in дестабилизация.

\subsection{Motive 2: Turning inside out}

A variation on the theme of the destruction of the world is the motive of being turned inside out: пск. наниччку 'with the wrong side outward', 'not properly, not as it should be': Наничку - значыт жызнь такая перяила, фсе пьють, не так, как раньшэ (ПОС 20: 110). In this nomination, the idea of destructuring a critical characteristic is imprinted: the integrity of the world is destroyed in such a way that the internal and the external change places, and the ugly becomes visible.

\subsection{Motive 3: Death and destruction}

Changes in society are marked in the naïve linguistic consciousness as destruction, as evidenced by the use of derivatives of the verbs бить and рушить: яросл. разбúmue 'breaking the established order, customs, discord, strife': Такое нынче разбитие пошло: брат на брата, сын на отия, молодежь табак курит, картами играет (СРНГ 33: 263), арх. ру́шиться 'to break or change (about customs, way of life, traditions)' : Да в домах всё рушится, по-новому в домах-то, по нонешней-то моде (СРГК 5: 587). Let us once again focus on the second example in which the emphasis is put on the emergence of the new: for the bearer of folk culture, the category "new" has a built-in meaning 'new, destructive for the past'. The appearance of the new is not recognized as a constructive, positive change, on the contrary, this novelty serves as a frightening sign of the "dismantling" of the old way of life. To complete the picture, let us recall that the moral fall of a person is also interpreted as his death: литер. погиба́mь 'to descend, lead an immoral life', поги́биий 'descended, lost; leading an immoral, perverse life' (ССРЛЯ 10: 164, 166), дон. сгубиться 'to go the wrong way': Сгубился парень: пить стал (СРНГ 37: 47). These metaphors are familiar both in the standard language and in Russian dialects. The motive of destruction is thus realized in the characteristics both of an individual and the society as a whole.

\section{Spatially dynamic motives in denotations of social changes}

Commenting on social transformations, native speakers of the Russian language include in their speech lexical units whose inner forms refer to a chronotope. So, images realizing the idea of disappearance arise in speech. "The spatial-temporal 
principle of motivation" as one of the motivations that are relevant in the semantic field of disappearance has been described in detail in the work of L. Feoktistova (ФЕОКТистова 2003: 18, 61-64).

\subsection{Motive 1: Removal in space, disconnection}

Society and custom are connected by subject-object relations therefore in several nominations, the focus is on custom as an object (thing, entity) which is managed by a person. The internal form of these words embodies the motivational characteristics "to put aside, place in space far from oneself". Images of manipulation with objects appear: "to set aside from yourself" and "to throw the subject away". The motive of removing, shifting to another place, extracting something (as if it were an object) from oneself is realized in the apx. отста́вить 'to stop observing, forget a custom or a tradition': В старину свадьбы делали больши. Все теперь отставлено (СРГК 4: 331) and in the перм. забро́шено 'a resultative to забросить - to stop doing something, stop observing customs': Мужикам широкие кушаки были, опояски наплетут. Нынче их (опояски, кушаки) заброшено; Взамуж идут - благословляют, в ноги падают. Нынче заброшено (АС 1: 285). These illustrative contexts have similarities in that they are passive constructions since the predicates are expressed by past passive participles. The subject is not actualized syntactically although it is semantically implicitly implied in the predicates that prompt a generalized actor acting as the executor of the manipulation: отставлено и заброшено - by whom?

A somewhat different variant of the realization of the motive of disconnection is embodied in моск., омск., том. отпада́mь 'go away into the past, disappear (about holidays, customs, etc.)': Видно, что все это отпадет, все эти обычаи отпали - о праздновании святок, масленицы и т. д. (СРНГ 24: 264). This record of dialect speech also contains a characteristic of the most important object of social reality - custom. Its self-rejection as unnecessary is figuratively represented.

\subsection{Motive 2: Disappearance by the movements of natural elements}

Trying to pick up the right designation for transformations in the organization of the life of a society, native speakers exploit the idea of movement. A parallel is drawn between the dynamics of social changes and the movement of natural elements (air or water).

The image of permanent dissolution in the air is a variant of the metaphorical concretization of the idea of extinction. The notion of wind as a "causative agent of extinction" (ФЕоктистовА 2003: 58) lies at the heart of apх. дух вы́ветрился 'habits and customs have been lost': Нонь дух-то тоже выветрился этому портяному. Один лишь матраи домотканый, крепкой, он долго стоял (СРГК 2: 12), cf. the following language facts: literary как (словно, точно) ветром сдуло 'about the sudden disappearance of someone or something' (СлРЯ 1: 158), literary выветриться 'to disappear, be destroyed by the action of the wind or fresh air' (ССРЛЯ 1: 248). They are cited in the work of L. Feoktistova as representatives 
of "a model that explicates the idea of displacement under the influence of the environment” (ФЕоктистовА 2003: 58).

If the movement of the air - the wind - appears in the form of a force acting on a given object (the image "everything is blown away by the wind"), the movement of water is interpreted differently: it is not a force that exerts pressure and takes away something but water constantly moving away in the distance (flowing), possibly, a dwindling source. The flow of water is one of the most famous metaphors of the movement of time. Therefore, in the internal form of the analyzed words, it is expected that the motivational characteristics "to outflow" turns up, depicting the disappearance through the movement of water: перм. истека́mь 'to lose one's best qualities, become worse': Молодежь нынче пошла, все истекат, истекат (СПГ 1: 366), cf. dialectal words of the same root, also describing disappearance: волог. пойти на стёк 'to go to ashes, vanish' (КСГРС), свердл. стечь 'to disappear, vanish, run out' (КДЭИС). For more details, see ФЕОКТИСтовА 2003: 118.

\section{The motive of qualitative change in denotations of social changes}

The dynamic component in the semantics of the notation of social transformations (that is, the emphasis on a turning point, a transition from one state to another) can be realized in the variants of "losing one's own properties" and "acquiring uncharacteristic (alien) features" and be objectified, for example, through genetic, ethnic, degradation, and vital (temperature) metaphors.

\subsection{Motive 1: The loss of one's own properties, degeneration}

Standard language facts вырождаться, вырождение have an internal form referring to a genetic metaphor. The motivation can be interpreted as follows: "to be born in a worse quality; cease to be born": literary вырождение "the deterioration of the breed of next generations compared to previous ones; the loss of higher physical or mental attributes, qualities; degeneration': Перед вами, господа присяжные заседатели, яркий пример физического и нравственного вырождения (Куприн: С улицы); вырождаться 'to deteriorate in its nature, losing some physical or mental signs, qualities, deteriorate with generations; to decline, melt; to die out (about people and animals)': Этот ветеран земской полиции любил рассказывать удивительные анекдоты о самом себе и своих сослуживиах, не скрывая своего презрения к выродившимся чиновникам нового поколения (Герцен: Былое и думы) (ССРЛЯ 2: 1198). In definitions, the word поколение is used, which objectifies the social sounding of the lexemes interpreted.

Negatively evaluated social transformations are also described through verbal derivatives of the word русский: арх. изрусе́ть 'to change, transform, be reborn': Ране-то песни певали, а топерь изрусело всё, топерь-то телевизор (СГРС 4: 325); волог. изрусе́ть 'to desolate, depopulate': Деревня была большая, а ноне вся изрусела (СВГ 3: 16); карел. (рус.) обрусе́ть 'to become abandoned, come to desolation': Все уезжают, так дома всё стары стали, разрушились, всё пусто стало, обрусело всё, нищего не стало, плохо ето (СРГК 4: 112); перм. 
обрусе́mь, обруси́m ь 'to acquire peculiarities charasteristic of the urban, industrial setting, while losing in a way the original rural features': Всё опустело - шум, трактора, машины! А раньше-то были птицьл. Теперь всё обрусело (АС 3: 99). Cf. also the context to the карел. (рус.) обрусеть 'to become more civilized, culturally higher': Все обрусели люди нонеџька, раньше жили -Богу молились, теперь не верят, ныне-то, говорят, обрусело всё (СРГК 4: 112). The comparison of the explanation of meaning and the illustrative context in the last example shows the ambivalence of perception of changes: the emergence of a new culture means the repression and destruction of the previous "cultural layer". Therefore, the definition reflects one aspect of the process ("to become culturally higher" this is probably the lexicographer's interpretation) but the context reflects the flip side (mеперь Богу не молятся, не верят - this is the view of the dialect speaker). In the first two examples, due to the prefix, there is especially clearly a motive "to come to nothing, degenerate, dwindle". E. Berezovich dedicated a section of his book to the semantic derivatives of the ethnonym русский and the toponyms $P y c b$, Россия, Расея, which, among other numerous semantic-pragmatic development lines, highlights in this nest the lines 'savagery, desolation' and 'the loss of important and positive features of rural life' (БЕРЕзОВич 2014: 110-156). The causes of their emergence are explained by E. Berezovich with regard to various possibilities and linguistic processes which can be assumed in respect of the derivatives of the nest in question: "These meanings could occur as a result of the logical unfolding chain of обрусение - changes - rebirth - degeneration... The meaning of dilapidation and devastation in the verb изрусеть are formed apparently due to the negative prefix $u_{3}$, while the motivating verb pycems has the opposite meaning... We can assume external influences, i.e. interacting with other nests... primarily the nest of *brusiti 'to rub, scrape or sharpen'... Finally, words with the meaning of degradation can be influenced also by *rudss 'light' (cf. the meaning of molting, losing one's normal colour). It seems that this effect is manifested at the level of attraction which may fuel and partly guide the potency of its own of the nest pyc'Rus', Russian' (БЕРЕзОВИч 2014: 129-131).

\subsection{Motive 2: Acquiring similarity to representatives of a foreign nation}

The perception of the world in the categories "one's own - somebody else's" characterizes human thinking in general, and for the representatives of traditional folk culture, this opposition structures the relationship between home space and neighbouring space, village and city, their own ethnos and strangers. Thus, the internal form of перм. таси́мцами жить 'to live not respecting the generally accepted customs' appeals to the motive of ethnic alienity: Тасимцами мы сейчас живем, родятся - не крестятся, помрут - не отпеть (СПГ 1:264). The structure of this phrase includes the noun macúmubl - a word of unclear origin which can be associated with the Turkic anthroponym Тасим mentioned in the genealogies of Tatars including those living in the territory of the present-day Perm Krai, where the above expression was registered. In addition, in this region, there is a village called Кояново, formerly known as Каянова, having a second name - Тасимка. 
This nomination is associated with the name of Тасим Маметов, the head of the family of local miners, a village elder. Since this is a Tatar-Bashkir settlement, it can be assumed that the basis of the analyzed expression contains a reference to an ethnic image that symbolizes the opposition of one's own and somebody else's. The cases of using the "typical name" as a metonymical designation of the representative of an ethnos are known in the standard language and in dialects (Ванька, Джсн, Ганс, Изя, etc.); therefore, the appearance of deanthroponimic formations can be quite expected among the designations of disapproved lifestyle and human behaviour (тасимиами жить - from the name Тасим), just like the emergence of expressions including such names, $\mathrm{cf}$. the Permian comparative expession $\kappa a \kappa$ абдул 'about a man who differs from Russians by his appearance or behaviour': Tbl чё, как абдул - за стол в шапке?! (AC 1: 39).

To denote people who do not observe customs and everyday rituals or behave contrary to accepted norms, dialect speakers use ethnonyms, i.e. words denoting a person of non-Russian nationality in their primary meaning: пск., твер. чухна́ 'who sits down at the table without praying' (КСРНГ); сиб. ру́сский не́меu 'one who does not observe strictly Russian religious customs, such as fasting periods': Э, брат, Терентий, держись лучше старины, а не будь русским немием, так бог счастья даст (СРНГ 35: 272); apx. тата́рин 'about a man who does not observe any fasting days' (СРНГ 43: 303); перм. вогу́л (gen., expr.) 'about a man who deviates from the norms adopted by Russians in behaviour, speech, clothing, and in some respect resembles a Mansi': Вогул ты, Зойка! Варёно не ешь; Унас, который оденется плохо, ругают: вогул ты (АС 1: 137); перм. (expr.) вотя́к 'about a man who deviates from the norms of Russian speech': Это который noрусски говорить как следует не может, вот и вотяк (АС 1: 151).

\subsection{Motive 3: The loss of "human status"}

Negative changes in a person or a generation are represented in the naïve linguistic consciousness as the loss of human shape: карел. (рус.) оскоте́ть 'to lose human moral qualities': Нет ничего святого, люди оскотели, откоснулся Бог-то от всех, то ли будет (СРГК 4: 245). The zoological metaphor (оскотели < скот), as it is shown in the illustrative context, arises in describing the changes in moral and ethical spheres: faith, the spirituality of people, which, accordingly, is part of God's jurisdiction. The semantic presumption of the lexeme оскоте́m $b$ is constituted by the sense "faith distinguishes man from an animal". On the basis of this cognitive structure, the emergence of the word describing the loss of morality becomes possible through the image of the transformation of man into an animal (see the motivational attribute of скоm 'cattle' in the internal form of the word).

\subsection{Motive 4: Desacration, acquiring of inferior properties}

The generalization of the negative assessment of changes can be observed in language units based on the characteristic of "rotten, bad". The verb опоганиваться having the meaning 'become dirty, rotten': В глазах народа опоганилось слово 
«nатриотизм»... (Калинин: О коммунистическом воспитании), 'to get desecrated' (ССРЛЯ 8: 917) is used in Arkhangelsk dialects to characterize the way of life of people who have lost their customs: apx. опога́ниться 'to stop observing old customs, traditions, rules of behaviour': Мы дак опоганились: когды переверну стакан, а когды уж не переверну (СРГК 4: 217). The vector of changes from "good" to "bad", just like the figurative transformation of a person into an animal, presents a variation on the topic of degradation.

\subsection{Motive 5: Cooling down}

The metaphor of temperature is embodied in the карел. (рус.) остьіm 'to forget, get out of habit, custom': Теперь не ходят праздничать, все остыло (СРГК 4: 266). The decrease in temperature is associatively bound with the weakening of the activity of living matter, dying, so we can talk about the presence of a "vital" image here, or more precisely, the motive of the loss of vitality.

\section{Motives of disorder in denotations of social changes}

Changes in society are qualified, among other things, as a violation of order, chaos. The nominator transmits this idea by means of a choice of such motivational signs as "to mix up" and "to get lost".

5.1. Motive 1: Disorganization: mixing things alien to each other

The interpenetration of customs of different peoples is interpreted by the representatives of traditional folk culture as disorganization of everyday life: an undesirable change that undermines the foundations of a certain human community: новосиб. перемеша́ться бо́жьему с гре́шным 'to mix up by violating the old order': Teперь-то перемешалось божье с грешным, раньше за татарина не в жисть бы не пошла (ФЕдОРОв 1983: 134). In the expression, in addition to the verb that directly calls the anomaly of the disturbance of order, there are words that outline the area of transformation - religious institutions determining the organization of life. The metaphor not so much indicates a mixture of dissimilar things as of things being in opposition to each other: permissible (correct) and forbidden (wrong).

It is remarkable that a person who gets into a situation when he is forced to belong to several ethnic communities feels the mixture of different traditions in his life as a confusion and puts this feature as the basis of the nomination: мурман. nýтаться 'to adapt to different customs': А мне поневоле путаться надо, в трех измерениях: родилась карелкой, училась по-фински, а жить надо по-русски (СРГК 5: 358).

\subsection{Motive 2: Destabilization, disorientation}

Social transformations are conceptualized through a dynamic metaphor: they are represented as a result of a person's disorientation in his personal life: мурман. заблудитться 'to live without observing the traditional way of life associated with 
faith in God and going to church': Здесь все заблудились, ни постов, ни иеркви (СРГК 2: 82), cf. перм. заброди́mь 'to start behaving oneself indecently, commit offenses': Попал в милицию, добродил, мол, себе. Забродил, попал и добродил (AC 1: 285). If on the basis of the image of the loss of the system of coordinates (that is, the metaphor of aimless wandering), we can reconstruct the notion of the norm "from the inverse, from the opposite", it turns out that in the perception of the native speaker the norm is a "signpost" or a reference point with which the direction of motion is checked when choosing one's path (first of all, in situations of moral choice).

In similar language units, a spatially dynamic image is exploited that is defined by the very structure of the word with a prefix expressing the semantic component of inchoativeness, and a root that has the meaning of motion (забродить 'to start wandering'). The word забродить is characterized by the primary meaning of the beginning of a random aimless movement which contains the potential necessary for the emergence of the secondary meaning of social destabilization, i.e. what is important is exactly the combination of the semantic components 'the beginning (of movement)' and 'the randomness (of spatial shifts)' where each component has its own capacity for the production of secondary meanings: the inchoativity of the action gives growth to the meaning of 'the loss of stability' and then to the meaning of destabilizing the ethical foundations of human existence (which are meant to be fixed), and the semantic component of randomness of movements is modified to the meaning of 'the lack of order due to the lack of guidelines' and further to the meaning of moral disorientation.

The image of a disordered aimless movement resonates with the metaphor of "distortion" of a person's life path which "without anomalies (in a normal case)" is represented as a line, a vector, a directional movement: перм. идти́ во́зле доро́zи 'to lead a wrong way of life': Если отеи не воспитат парня, дак ведь он возле дороги пойдет (СПГ 1: 343), том., омск., кемер., новосиб. не по пути́, путе́, путю́ 'not as it should be; in a bad way': Живет плохо, значится, не по путю; Не по пути сделал - поступил плохо, не по-честному; Нет, чтобы сделать, как все, а то всё выходит не по путе (СРГС 4: 69), пск. пойти не по той пути 'to act in the wrong way, unjustly' (СПП 2001: 64), среднеобск., тюмен., том., кемер., орл., калуж. сби́ться с путя 'to start behaving badly, start to lead a rampant or dissolute life' (СРНГ 36: 172, 173), печор. в худу́ю сто́рону nойтú 'to take the path of vice': И пошел Петька в худу сторону, разбойничать стал, пить, воровать; Пошла девка в худу сторону, еще смолоду во блуд пошла (ФСРГНП 1: 115), смол. сверте́ться 'to change one's behaviour in a bad way, get off the right track': Девка свертелась (СРНГ 36: 242).

\section{Conclusion}

Thus, the analysis of dialectal discourse shows that the bearers of Russian dialects in making judgments about the state of society are attentive to the performance of religious rituals, everyday ritualized actions, and the observance of traditions. 
Other linguists who study the traditional linguistic image of the world through the prism of the vocabulary of Russian dialects come to the same conclusion, cf., for example, the remark made by S. Belyakova on the role and the significance of the categories "custom" and "past" in peasant culture: "The significance of the past is especially great for a traditional society where experience is of particular value because of the repetition of the basic elements of existence... Traditional culture lacks certain material forms of preserving the past (monuments, museums) though old objects can be preserved within a family or a clan. The more important are immaterial forms: customs, rituals, and verbal means. A special focus on the past (passéism) is an important feature of the worldview of a bearer of traditional culture" (БЕляковА 2005: 84). A disapproving attitude toward social transformations is characteristic of the inhabitants of Russian villages during the transition to a new society in which customs lose their positions and regulating function. At the same time, the concentration of material on the negative assessment of social transformations should not lead us astray and create the illusion as if modern reality were exclusively perceived by the bearers of traditional culture as bad. The material and economic conditions of life of different generations are estimated quite differently, e.g., informants indicate that peasant labour was very difficult due to the lack of machinery. In the record of dialect speech given by M. Pelipenko, the comparison of "before" and "now" ends with a positive assessment of the modern conditions of life: Mь так пожили, мучились, сейчас хорошо живём (ПЕлиПенко 2009: 22).

Russian common and dialectal words and phrases extracted from dictionaries and archives register negative connotations for language units that denote social transformations (всё остьло, разбитие пошло, etc.). In search of ways to conceptualize the notion of cardinal changes in the life of society and their perception (evaluation) by native speakers of Russian, the motives behind the nominations were analyzed in this paper. Four groups of motives were revealed: the motives of destruction (loosening, turning inside out, and death); spatially dynamic motifs (moving away and disappearance); the motives of qualitative changes (the loss of one's own properties and status, the acquisition of similarity with representatives of a foreign nation, the acquisition of worse properties, cooling down) as well as the motives of confusion (mixing of different cultures and disorientation).

Reflections on the linguistic expression of the negative evaluation of social transformations that lead to the reconstruction of approving connotations of the past suggest that it is possible to compare this phenomenon with the one called ностальгия 'nostalgia' in the present-day Russian language. In this latter case, by that we usually mean longing for the past along with its idealization. For example, sociologists are actively involved in the discussion of the social phenomenon of "Soviet nostalgia" - public sentiments that are about regretting the era of stability and great achievements that have gone by with the collapse of the USSR as an integral state (Очкина 2012: 52, Смолина 2014, etc.). However, for the bearers of traditional culture, it is not the sadness of loss that is the core of their disapproval of changes and positive memories of the past but the eschatological sense of the end of time and the destruction of the world. 


\section{List of abbreviations}

арх. - архангельское

волог. - вологодское

дон. - донское

калуж. - калужское

карел. (рус.) - карельское: записанное

в русских говорах на территории

Республики Карелии

кемер. - кемеровское

моск. - московское

мурман. - мурманское

новосиб. - новосибирское

онеж. - онежское

омск. - омское

\author{
орл. - орловское \\ перм. - пермское \\ печор. - печорское \\ пск. - псковское \\ ряз. - рязанское \\ свердл. - свердловское \\ сиб. - сибирское \\ смол. - смоленское \\ среднеобск. - среднеобское \\ твер. - тверское \\ том. - томское \\ тюмен. - тюменское \\ яросл. - ярославское
}

\section{References}

$\mathrm{AC}=$ Словарь говора д. Акчим Красновишерского района Пермской области (Акчимский словарь). Вып. 1-6. Пермь, 1984-2011.

БЕЛЯковА 2005 = БЕЛяковА С. М. Прошлое и будущее в диалектной картине мира. Вестник Воронежского государственного университета. Серия «Лингвистика и межкультурная коммуникация» 2005/2: 79-88.

БЕРЕЗОВИч 2007 = БЕРЕЗОВИч Е. Л. Язык и традиционная культура: этнолингвистические исследования. Москва: «Индрик», 2007.

БЕРЕЗОВИЧ 2014 = БЕРЕЗОВИЧ Е. Л. Русская лексика на общеславянском фоне: семантико-мотивационная реконструкция. Москва: «Русский фонд содействия образованию и науке», 2014.

ГРИЦКЕВИЧ-НовиКОВ 2011 = ГРИцКЕВич Ю. Н., НОВиКОВ В. Г. Концепт «Мода» в диалектном дискурсе. Вестник Псковского государственного педагогического университета. Серия «Социально-гуманитарные и психолого-педагогические науки» 2011/15: 77-80.

Даль = ДАЛь В. И. Толковый словарь живого великорусского языка. Т. 1-4. Москва: «Русский язык», 1981-1982.

КДЭИС = Картотека Диалектного этноидеографического словаря русских говоров Среднего Урала (Кафедра русского языка и общего языкознания Уральского федерального университета имени первого Президента России Б. Н. Ельцина, Екатеринбург).

КСГРС = Картотека Словаря говоров Русского Севера (Кафедре русского языка и общего языкознания Уральского федерального университета имени первого Президента России Б. Н. Ельцина, Екатеринбург).

КСРНГ = Картотека Словаря русских народных говоров (ИЛИ РАН, Санкт-Петербург).

Куликовский 1898 = Куликовский Г. И. Словарь областного олонеикого наречия в его бытовом и этнографическом применении. Санкт-Петербург: «Типография Императорской Академии наук», 1898.

ЛЕОНтьЕВА 2012 = ЛЕОНТЬЕВА Т. В. Диалектная лексика со значением социальной деградации: семантический анализ. Научнылй диалог 2012/3: 91-106. 
НОСС 2003 = Новый объяснительный словарь синонимов русского языка. Москва: «Языки славянской культуры», 2003.

ОССОВЕЦКИЙ 1969 = ОССОВЕЦКИЙ И. А. (ред.) Словарь современного русского народного говора (д. Деулино Рязанского района Рязанской области). Москва: «Наука», 1969.

ОчкинА 2012 = ОчкинА А. В. К вопросу о социальной природе «Советской ностальгии». Известия Пензенского государственного педагогического университета им. В. Г. Белинского 2012/28: 50-57.

ПЕЛИПЕнко 2009 = ПЕЛИПЕнко М. В. Социальная семантика в структуре диалектного слова (на материале тамбовских говоров). АКД. Тамбов, 2009.

ПОС = Псковский областной словарь с историческими данными. Вып. 1-26. Ленинград / Санкт-Петербург: «Издательство ЛГУ / СПбГУ», 1967-2015.

СВГ = Словарь вологодских говоров. Вып. 1-12. Вологда: «Русь», 1983-2007.

СГРС = Словарь говоров Русского Севера. Т. 1-4. Екатеринбург: «Издательство Уральского университета», 2001-2009.

СлРЯ = ЕВГЕНьЕВА А. П. (ред.) Словарь русского языка. Т. 1-4. Москва: «Русский язык», 1981-1984.

СмолинА 2014 = СмолинА Н. С. «Советское» в постсоветском пространстве: анализ ностальгических сообществ. Вестник Челябинского государственного универсиmeта 2014/17: 133-136.

СПГ = БОРИСОВА А. Н., ПРОКОШЕВА К. Н. (ред.) Словарь пермских говоров. Т. 1-2. Пермь: «Книжный мир», 2000-2002.

СПП 2001 = Мокиенко В. М., НикитинА Т. Г. (сост.) Словарь псковских пословии и поговорок. Санкт-Петербург: «Норинт», 2001.

СРГК = ГЕРД А. С. (ред.) Словарь русских говоров Карелии и сопредельных областей. Вып. 1-6. Санкт-Петербург: «Издательство Санкт-Петербургского университета», 1994-2005.

СРГС = ФЕДОРОв А. И. (ред.) Словарь русских говоров Сибири. Т. 1-5. Новосибирск: «Наука», 1999-2006.

СРНГ = Словарь русских народных говоров. Вып. 1-49. Москва-Ленинград / СанктПетербург: «Наука», 1965-2016.

ССРЛЯ = Словарь современного русского литературного языка. Т. 1-17. Москва: «Наука», Ленинград: «Издательство АН СССР», 1950-1965.

ФЕДОРОв 1983 = ФЕДОРОВ А. И. (ред.) Фразеологический словарь русских говоров Сибири. Новосибирск: «Наука», 1983.

ФЕОКТИСТОВА 2003 = ФЕОКТИСТОВА Л. А. Номинативное воплощение абстрактной идеи (на материале русской лексики со значением 'пропасть, исчезнуть'). Дисс. ... кандидата филологических наук. Екатеринбург, 2003.

ФСРГНП = СТАВШИНА Н. А. (сост.) Фразеологический словарь русских говоров Нижней Печоры. Т. 1-2. Санкт-Петербург: «Наука», 2008.

ЭССЯ = ТРУБАЧЕВ О. Н. (ред.) Этимологический словарь славянских языков. Праславянский лексический фонд. Вып. 1-35. Москва: «Наука», 1974-2009. 